\title{
KØNSLIGT HIERARKI ELLER RELIGIØS ANDROGYNI
}

En læsning af 1 Kor 11,2-16

\author{
Birgitte Graakjær Hjort
}

Få nytestamentlige tekster har vakt en diskussion og harme, der kan måle sig med den, der udspringer af en læsning af 1 Kor 11,2-16. Nogle opfatter Paulus som eksponent for en uhørt rigiditet og en fastholdelse af patriarkatet. Det hierarkiske ræsonnement i 1 Kor 11,2-16 siges tilmed at bringe ham i et modsætningsforhold til hans egen fundamentale forkyndelse af enhed og lighed i Kristus mellem kønnene, sådan som han prægnant og aforistisk har udtrykt det i Gal 3,28 (Bussmann 1983, 256f; Wire 1990, 185f). Andre har imidlertid ikke hæftet sig ved en eventuel inkongruens, idet de indskrænker ligheds-

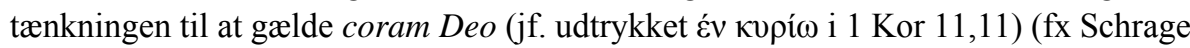
1995, 518 f og 525; sammenlign Boucher 1969, 56f). ${ }^{1}$ Når denne sidste læsning fra tid til anden fremføres i den moderne teologiske og kirkelige debat, gøres Paulus i reglen til eksponent for en principiel teologisk begrundelse for, at kvinden er underordnet manden, i hvert fald i en ekklesiologisk, gudstjenestelig sammenhæng. ${ }^{2}$ Netop ved at argumentere ud fra skabelsen skulle Paulus således have præsenteret et hierarki, som til enhver tid sidenhen er tilskrevet normativ gyldighed i forholdet mellem kønnene (Waltke 1978, 46 og 56f; Wilson 1991, 460-62).

Begge disse receptioner af teksten forudsætter, at Paulus i 1 Kor 11,2-16 har anskuet forholdet mellem mand og kvinde som et principielt over- og underordningsforhold, uanset om han har gjort det gældende generelt, eller om han har begrænset det til gudstjenestelig sammenhæng. I min diskussion af disse receptioner og $\mathrm{i}$ argumentationen for en alternativ fortolkning af perikopen på det historiske plan vil jeg gøre følgende: I. Problematisere at Paulus skulle have plæderet for et over- og underordningforhold mellem mand og kvinde. II. Søge at påvise at konteksten udgør en afgørende hermeneutisk nøgle til at afklare, hvad der i stedet var Paulus' anliggende. III. Afdække tekstens argumentation. IV. Fremsætte en foreløbig konklusion. V. På baggrund af resultaterne af II og III vil jeg afslutningsvis drøfte tre mulige forklaringer på synkretismen i 1 Kor 11,2-16 ved at forholde mig til hhv. en indre-kristen, en sociobiologisk og en dionysisk hypotese og dermed nå frem til en endelig konklusion i VI.

\footnotetext{
${ }^{1} 1$ Kor 11,3-16 udlægges da som en tekst, hvor kvinden underordnes manden socialt set, men stilles lige med ham over for Gud.

${ }^{2}$ Forekomsten af bøn og især profeti taler for, at det drejer sig om en gudstjenestesammenhæeng: Profeti (fx 1 Kor 12,7-10 og 14,3-5.22) og bøn (fx 1 Kor 14,13-15) har hørt hjemme i gudstjenesten.
} 


\section{Teksten som et værn om mandens overordnede status}

Flere undersøgelser har vist, at tilhylning og hårlængde i Paulus' samtid ikke kun var et æstetisk spørgsmål om mode, men at det i visse grupper også blev opfattet som et religiøst signal. Isaksson har således peget på, at hverken de jødiske præster eller rabbinerne måtte rage sig eller have langt hår; de skulle derimod være kortklippede. Det korte hår skulle symbolisere, at de var loyale over for den jødiske religionsudøvelse og ikke deltog $\mathrm{i}$ andre kulter. Langt hår kunne således være et kendetegn på deltagelse i hedensk kult (Isaksson 1965, 161-64, 167f og 184). De jødiske kvinder derimod skulle være tilhyllede og have langt hår som symbol på deres underordning i forhold til en mand (far, ægtemand osv.). Hvis en kvinde gik med løsthængende hår uden for hjemmet, er det muligvis ikke blot blevet opfattet som en krænkelse af mandens autoritet, men mere vidtrækkende som første skridt i retning af gteskabsbrud (Isaksson 1965, 161-64, $167 \mathrm{f}$ og 184; Fiorenza 1984, 228; sammenlign D’Angelo 1995, 141f). ${ }^{3}$

Hvis 1 Kor 11,2-16 fortolkes på denne baggrund, bliver meningen i v. 5-6, at det hoved, kvinden bringer skam over, ikke er hendes eget, men mandens (jf. kefalcestrukturen i v. 3). Når Paulus argumenterer med, at kvinden handler skamfuldt, hentyder han dermed til, at hendes utildækkede optræden under gudstjenesten krænker manden ved at angribe hans status som overordnet sin hustru. ${ }^{4}$

Svaghederne ved denne udlægning er mange: For det første var størsteparten af den korintiske menighed hedningekristne, for hvem det ikke var umiddelbart indlysende at tilskrive de jødiske kønsrollemønstre nogen normativ status. Paulus ville derfor næppe kunne alludere til sådanne jødiske traditioner og jødisk rangorden uden at gøre nærmere rede for, hvori det skamfulde (v. 4-6) skulle bestå. For det andet er det problematisk, at ovenstående fortolkning forudsætter, at teksten kun (eller primært) rummer formaninger til agtefceller i gudstjenesten, da denne givetvis også har haft enlige deltagere (jf. 7,8.25-28.32-34.36-38.40). For det tredje er det problematisk i forhold til Paulus' teologi som helhed at hævde, at han skulle have leveret en grundig teologisk argumentation med det ene formål at værne om det ene køns ret til at bevare en overordnet status i forhold til det andet. Det ville stride imod Paulus' generelle skepsis over for korinternes optagethed af egne rettigheder og hans formaninger til dem om i stedet at bestræbe sig på at tjene og gavne andre. Fx lader Paulus de svages samvittighed markere grænsen for den enkeltes frihed til at spise afgudsofferkød. Maksimen for korinternes handlinger

\footnotetext{
3 D'Angelo peger på, at Paulus' samtidige kan have opfattet de korintiske kvinders protest mod at være tilhyllede som et forsøg på at usurpere mandens ret til at tage det seksuelle initiativ i forhold til kvinden.

${ }^{4}$ Denne udlægning forudsætter, at $\kappa \varepsilon \varphi \alpha \lambda \eta ́$ anvendes metaforisk i betydningen "overhoved", dvs. at relationen mellem mand og kvinde tænkes som et over- og underordningsforhold. Argumenter for denne læsning finder vi hos Fitzmyer (1993a, 503-11, og 1993b, 52-59). Substantivet kan imidlertid også anvendes i betydningen "ophav" (jf. v. 8-9), således at relationen er kendetegnet ved samhørighed i væsen (argumentation herfor hos Bedale 1954, 211-15 og især Murphy-O'Connor 1980, 491f). Perriman (1994, 602-22) afviser begge disse tolkninger (hierarki og oprindelse) og argumenterer for en helt tredje brug af $\kappa \varepsilon \varphi \alpha \lambda \eta ́$, nemlig som billede og ære/herlighed.
} 
skal være at værne om fællesskabet og imødekomme ikke egne, men andres behov (8,913; 10,24.28-29a). Endvidere fremstiller Paulus sin egen given afkald på rettigheder som paradigmatiske handlinger $(9,12 b .15 .18)$. Dette er en realisering af kærlighedens grundlov, som består i ikke at promovere sig selv, men at søge det, der gavner de andre $(13,5)$. Også når det gælder forholdet mellem kønnene, sætter Paulus hensynet til den andens gavn højere end tilgodeseelsen af egne interesser (fx 7,3-4, hvor kriteriet ikke er den enkeltes ret, men hans eller hendes pligt). Hvis en tænkning i rettigheder og magt overhovedet er inden for horisonten i 11,2-16, ville det være mest nærliggende at forvente, at Paulus gjorde op med den bagvedliggende selvforståelse. I så fald ville irettesættelsen i v. 5-6 være rettet mod kvindernes forsøg på at tilrane sig den magt over (og ikke blot ligestilling med) mændene, som deres manglende tildækning og korte hår har symboliseret.

Selvom teksten i et jødisk perspektiv kunne læses som Paulus’ forsøg på at værne om mandens principielt overordnede status i forhold til hans hustru, byder en sådan læsning på så mange og tungtvejende vanskeligheder, at jeg vil betegne den som utroværdig. Teksten drejer sig med andre ord ikke om et generelt (evt. ægteskabeligt) overog underordningsforhold mellem mand og kvinde.

Når Paulus således ikke har villet give en teologisk begrundelse for, at kvinden principielt (jf. især argumentationen ud fra det skabelsesgivne) er underordnet manden, melder spørgsmålet sig: Hvad har han villet forholde sig til i 1 Kor 11,2-16? Besvarelsen af dette spørgsmål vil ske ud fra en analyse af tekstens placering i konteksten og af dens argumentationsrække.

\section{Tekstens struktur og kontekstens heuristiske funktion}

Efter præskript og proømium i 1,1-9 behandler Paulus i brevets første hoveddel 1,104,21 spørgsmålet om splittelser i menigheden. I anden hoveddel 5,1-6,20 fremsætter han en kritik af nogle moralsk angribelige forhold i menigheden. Brevets tredje hoveddel 7,1-14,40 er disponeret som svar på menighedens spørgsmål: I kapitel 7 spørgsmål om ægteskab og ugift stand, i kapitel 8,1-11,1 spørgsmål om afgudsofferkød og offermåltider, og i 11,2-14,40 spørgsmål, der berører gudstjenesten. 15,1-58 omhandler opstandelsen som fjerde og sidste hoveddel før postskriptet, 16,1-24.

Det er værd at bemærke, at afsnittet 11,2-16 om den sømmelige kontra skamfulde adfærd med hensyn til tilhylning ved gudstjenesten, er placeret mellem behandlingen af afgudsdyrkelse i 8,1-11,1 (med digressionen i kapitel 9 om Paulus som forbillede på at give afkald på egne rettigheder) og misforhold ved nadverfejringen i 11,17-34. Især placeringen af 11,2-16 efter afsnittet om afgudsdyrkelse (kapitel 8 og 10) er undertiden blevet opfattet som verificering af den ofte fremsatte interpolationshypotese (fx Cope 1978, 435f; Trompf 1980, 196-215; Walker 1975, 94-110). ${ }^{5}$ Der er imidlertid ikke ført

\footnotetext{
${ }^{5}$ Argumenterne for interpolationshypotesen bygger især på, at perikopen udgør et tematisk brud i forhold til
} 
tilstrækkelige argumenter for denne hypotese. Spørgsmålet er tværtimod, om ikke placeringen af afsnittet udgør en af de mest signifikante hermeneutiske nøgler til at forstå teksten med. Herfor taler både den forudgående kontekst i kapitel 8 og 10 og den efterfølgende i 11,17-34 med advarslen mod at lade nadvermåltidet udvikle sig til et drikkegilde (v. 17 og 20-22). ${ }^{6}$ Endvidere tyder den grundige argumentation på, at Paulus' advarsel er rettet mod et grundlæggende teologisk problem, ligesom indramningen af argumentationen i v. 2 og 16 indikerer, at problemet angår noget, der er så fundamentalt, at der er lære- (v. 2) og ordningsmæssig (v. 4) konsensus om det i de øvrige menigheder. Endelig er der en nøje overensstemmelse mellem udformningen af kefalcestrukturen, som tyder på, at over-underordningsforholdet er et religiøst anliggende (se afsnit III), og at konteksten indikerer en religiøs problematik, nemlig afgudsdyrkelse. ${ }^{7}$

Et af de spørgsmål, som således rejser sig, er om Paulus etablerer en særlig forbindelse mellem 8,1-11,1 vedrørende de kristne korinteres omgang med afgudsofferkød og 11,2-16 angående det aspekt af afgudsdyrkelsen, som har at gøre med køn og tilhylning? Er der med andre ord en forbindelse mellem de to former for afgudsdyrkelse: den, der har med afgudsofferkød at gøre (kapitel 8 og 10), og den, der vedrører køn (kapitel 11)? I kapitel 8, hvor Paulus belyser forholdet til afgudsofferkød ud fra distinktionen mellem de rigoristiske (de svage) og de libertinistiske (de stærke), er det teologiske hovedsynspunkt monoteismen $(8,4-6)$ samt antagelsen af, at kød ikke gør fra eller til over for Gud $(8,8)$. En teologisk begrundelse for at afholde sig fra at spise kødet giver Paulus ikke. Når han alligevel formaner til forsigtighed i omgang med kødet, skyldes det hensynet til de svage (8,9-13), som identificerer spisning af kødet med deres tidligere afgudsdyrkelse $(8,7)$. Skønt der ikke teologisk er noget til hinder for at spise kødet, formaner Paulus til at undlade det, hvis det bringer svage brødre til fald (8,9-13). I kapitel 10 skærpes dette ekklesiologiske og missionsteologiske hensyn i forhold til selve afgudsdyrkelsen. Det er nu ikke længere alene hensynet til de andres svage samvittighed, Paulus er optaget af. Med en typologisk udlægning (10,6-11) af ørkenvandringsbegivenhederne (10,1-5) advarer han korinterne ikke blot mod at foranledige andre til afgudsdyrkelse eller frafald, men også mod selv at blive afgudsdyrkere (10,7.14). Det ekklesiologiske og missionsteologiske hensyn lades imidlertid ikke ude af betragtning. Det fremgår af nadverforståelsen: Nadveren bør fremme menighedens enhed $(10,17)$; endvidere af Paulus' indskrænkning af den enkeltes autonomi til fordel for opbyggelse af fællesskabet (10,23-24, eksemplificeret i 10,25-11,1). Selvom Paulus således principielt tillader korinterne at spise afgudsofferkød (10,25-27), indskærper han dem deres

kapitel 8-10 og 11,17-34, og at der fremsættes et syn på kvinder, som er mere negativt end det paulinske (jf. Gal 3,28). Se Murphy-O’Connor (1976, 615-21) og Schrage (1995, 496f) vedr. kritik af hypotesen.

\footnotetext{
${ }^{6}$ Se uddybende nedenfor om synkretismen i Korintermenigheden.

${ }^{7}$ Også Wire ser placeringen af teksten i en sammenhæng, der omhandler afgudsdyrkelse, som en nøgle til at forstå problemstillingen. Ifølge hende er problemet, at de korintiske kvinder truer Guds ære, hvis de er utildækkede, fordi de derved betragtes som mandens ære og afglans (1990, 121 og 131-34).
} 
pligt til at afholde sig fra det, hvis det har negativ indvirkning på nogle i menigheden (10,23-24.28-29a.32).

Mens de stærke korintere har været eksponenter for et synkretistisk 'både-og' med hensyn til spisning af afgudsofferkød og Kristusfællesskab, har Paulus repræsenteret et 'enten-eller' $(10,21)$. Selvom han ikke principielt er uenig med de stærke, gør han dog op med det argumentationsgrundlag, deres adfærd hviler på, og især med de konsekvenser, adfærden får for andre: Nogle af korinterne har påberåbt sig særlig indsigt $(8,1-$ 2.7a.11), rettigheder til at spise afgudsofferkød $(8,9 ; 10,23.29 \mathrm{~b}-30)$, pneumatisk sikkerhed med hensyn til frelsen $(10,12)$, bl.a. på grund af dåbens og nadverens garanterede virkning (10,1-4). Måske har de ud fra monoteismen og en deraf følgende overbevisning om, at der ikke reelt findes nogen afguder, argumenteret for retten til at spise såkaldt afgudsofferkød $(8,4-6$,jf. også 10,19). Over for disse korintere har Paulus argumenteret med kærlighedens forrang frem for erkendelsen $(8,1-3)$, hensyn til svage brødres samvittighed og andre menneskers frelse $(8,7.9-11.13 ; 10,28-29 a)^{8}$ samt afgudernes realitet (8,5 og 10,19-21). Krænkelse af andres samvittighed er synd mod Kristus (8,11-12; 10,9). Han har advaret mod falsk sikkerhed i tiltro til 'sakramentalisme' (10,5-10.12) og mindet korinterne om deres fællesskab med Kristus og hinanden (10,16-17.23-11,1). Som sidste led i argumentationen har han henvist til det paradigmatiske i sine egne afkald for evangelieforkyndelsens skyld i analogi med Kristi afkald $(9,1-27$; 10,3311,1). Et forsøg på at danne sig et overblik over Paulus' argumenter, sådan som han stiller dem op over for korinternes, kunne se sådan ud:

\section{Paulus}

\begin{tabular}{|c|c|}
\hline $\begin{array}{c}\text { Kærlighedens primat } \\
\text { i forhold til erkendelse }\end{array}$ & $\begin{array}{c}\text { Indsigt } \\
\text { (gnosis) }\end{array}$ \\
\hline $\begin{array}{c}\text { Andres frelse/samvittighed } \\
\text { og egne afkald }\end{array}$ & $\begin{array}{c}\text { Egne } \\
\text { rettigheder }\end{array}$ \\
\hline $\begin{array}{c}\text { Falsk } \\
\text { selvsikkerhed }\end{array}$ & $\begin{array}{c}\text { Pneumatisk } \\
\text { sikkerhed }\end{array}$ \\
\hline $\begin{array}{c}\text { Fællesskab med } \\
\text { Kristus og menigheden. } \\
\text { Afguders realitet }\end{array}$ & $\begin{array}{c}\text { Monoteisme } \\
\text { og "sakramentalisme" } \\
\text { Ingen virkelige afguder }\end{array}$ \\
\hline
\end{tabular}

Det mest konsistente i Paulus' advarsel mod afgudsdyrkelse i 8,1-11,1 er det ekklesiologiske hensyn til brødrene og evt. det missionsteologiske hensyn til dem uden for menigheden. Maksimen for korinternes handlinger, hvad angår kødet, bliver derfor fælles-

\footnotetext{
${ }^{8}$ I 10,28 ser Paulus ud til at have udvidet perspektivet fra det missionsteologiske hensyn til brødrene til det missionsteologiske hensyn til hedningerne (dette forudsætter, at den omtalte person i 10,28 er en hedensk vært/gæstgiver eller en hedensk medgæst).
} 
skabet og de andres frelse. ${ }^{9}$ I en sammenfatning af 8,1-11,1 og som optakt til 11,2-16 formaner Paulus i 10,31-11,1 til at efterligne ham ved ikke at lægge hindringer i vejen for nogens frelse, hverken jøder, grækere eller Guds menighed. Denne efterligning er kristologisk begrundet. ${ }^{10}$

Hvad står vi tilbage med? Sammenfattende taler den forudgående kontekst $(8,1-$ 11,1) for, at Paulus vil advare mod en form for afgudsdyrkelse. Advarslen bygger i kapitel 8 og 10 overordnet set på hensynet til de andre. At svigte dette hensyn indebærer en ringeagtelse af Kristus selv. Det er tilsyneladende disse to aspekter, Paulus fører videre i 11,2-16, hvor han advarer mod at angribe Guds suverænitet (jf. v. 3 og 11-12) og menneskers kønspolaritet (v. 4-6). Det vil jeg vende tilbage til i næste afsnit (afsnit III).

Den efterfølgende kontekst $(11,17-34)$ afslører, at korinterne forvalter nadveren uværdigt (11,27), dvs. på en måde, så den mister sin karakter af at være Herrens måltid $(11,20)$. Årsagen er, at nogle spiser godt og drikker sig berusede, mens andre lider mangel $(11,20-22)$. Kun en analyse af teksten selv kan bidrage til at belyse, hvori forbindelsen mellem 11,2-16 og 11,17-34 kan bestå.

\section{Argumentationen i teksten}

Der er i 11,2-16 langt mere fokusering på argumentationen for formaningen end på præciseringen af dens indhold. I sin argumentation for, at kvinderne skal være tildækkede, knytter Paulus til ved en række forskellige forhold: fælleskirkelig tradition (v. 2 og 16); ære-skam og det moralsk konventionelle (v. 4-6 og 13); det skabelsesgivne (7-9), herunder mandens gudbilledlighed (v. 7); hensynet til englene (v. 10) og naturens lære (v. 14-15). Bortset fra den indledende og afsluttende henvisning til fælleskirkelig tradition (v. 2 og 16), bæres hele det udførlige ræsonnement v. 3-15 af to typer af argumenter, nemlig skabelsestanken og den moralske skik og brug, som udtrykkes ved hjælp af fænomenerne ære og skam. I den følgende tekstgennemgang vil disse to argumenter derfor stå centralt. Endvidere vil kefalce-strukturen spille en væsentlig rolle, da den på en særlig måde indikerer, hvad der er Paulus' ærinde i 11,2-16, og samtidig etablerer forbindelsen til konteksten.

I v. 3 gør Paulus rede for kefalce-strukturen: Gud - Kristus - mand - kvinde. Udformningen af strukturen er bemærkelsesværdig, men ikke desto mindre overset i størstedelen af den nytestamentlige eksegese. Den angiver, at det, Paulus opponerer imod, ikke vedrører mand-kvinde-forholdet som sådant (horisontalt), men mand-kvinde-forholdet $\mathrm{i}$

\footnotetext{
${ }^{9}$ Muligvis er dette missionsteologiske hensyn også til stede i 11,2-16 i argumentet vedrørende skam, idet korinterne ved at handle skamfuldt påfører deres fællesskab tab af social agtelse i forhold til dem udenfor. Når menigheden som gruppe mister ære i forhold til dem udenfor, formindsker den dermed sine muligheder for at tiltrække nye til fællesskabet, Gundry-Volf 1997, 153-55.

${ }^{10}$ Kristi selvhengivelse for andre kommer til udtryk både i behandlingen af afgudsdyrkelse $(8,11-12)$ og $i$ den efterfølgende kontekst om nadveren (11,24-25). Endvidere er det grundlaget for paradigmet i 13,5.
} 
et religiøst perspektiv (vertikalt). Hvis Paulus ville have gjort rede for et generelt forhold mellem kønnene, havde han næppe anført udsagnet om Gud som Kristi hoved. Strengt taget kunne han have nøjedes med kefalce-strukturens første led: manden som kvindens hoved. Dette udsagn er imidlertid indrammet af såvel et kristologisk udsagn om Kristus som mandens hoved som et teologisk udsagn om Gud som Kristi hoved. Hvis Paulus ville belære menigheden om kefalceforholdet mellem mand og kvinde som sådan, hvorfor så ikke gå direkte til sagen frem for at indlede udsagnsrækken med det kristologiske aspekt? Af stilistiske grunde, kunne man indvende: Hvis manden er kvindens hoved, bliver kefalce-strukturen underligt uafsluttet uden et analogt udsagn om, hvem der er mandens hoved. Det kristologiske niveau tjener således til at underbygge strukturens betydning. Men selv denne stilistiske betragtning forklarer ikke den afsluttende analogi vedrørende Gud som Kristi hoved. ${ }^{11}$

Også en sammenligning af kefalce-strukturerne i den nytestamentlige brevlitteratur viser, at hovedsynspunkterne er henholdsvis Kristus som hoved for kirken (Ef 1,22; 4,$15 ; 5,23$, Kol 1,18; 2,19) samt kefalceforholdet mellem mand og kvinde, og mellem mand og Kristus (Ef 5,23). Ingen andre steder i brevlitteraturen inddrages forholdet mellem Gud og Kristus, heller ikke når mand-kvinde-relationen er på tale. På denne baggrund bliver det evident, at Paulus i 11,3 udtaler sig om mand-kvinde-forholdet i et ganske bestemt perspektiv, nemlig det religiøse. Problematikken er således ikke mandkvinde-forholdet almenmenneskeligt betragtet, men i forbindelse med et religiøst anliggende. Især den forudgående (kapitel 8 og 10), men også den efterfølgende kontekst $(11,21)$ taler for, at dette religiøse perspektiv er afgudsdyrkelse. Det forklarer den overraskende og unikke indramning og især afslutning af kefalce-strukturen i 11,3 (tredje analogi: Gud-Kristus).

I v. 4-6 er ræsonnementet, at kvinder bør undlade at være utildækkede (og i yderste konsekvens at lade sig klippe eller rage) ved bøn og profeti, fordi det regnes for skamfuldt. Modsat er det skamfuldt for mænd at bede eller profetere tildækkede. Tekstens crux interpretum ligger i, at der ikke gives nogen forklaring på, hvorfor det regnes for skamfuldt. At antage, at det er jødisk køns- og ægteskabsmoral, der ligger bag, er ikke holdbart (jf. afsnit II). Ikke desto mindre peger v. 7-9 på, at det skamfulde består i at modsige det skabelsesgivne (efter jødisk udlægning), hvilket samtidig er en afvigelse fra konventionel skik og brug (v. 4-6 og 13).

Det er ikke umiddelbart indlysende, hvori den begrundende sammenhæng består

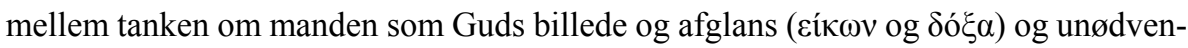
digheden af at være tildækket (v. 7). I dette ræsonnement udlægger Paulus den første skabelsesberetning i analogi med rabbinsk eksegese: Gudbilledligheden, som i 1 Mos 1,27 bestemmes som et særkende ved mennesket til forskel fra andre skabninger, ud-

\footnotetext{
${ }^{11}$ Fee gør opmærksom på, at det, i lyset af v. 3, hvor Kristus, ikke Gud, er mandens hoved, er overraskende, at manden i v. 7 bestemmes som Guds billede og ære $(1988,513)$. Selvom forklaringen er at finde i den bagvedliggende Genesistradition, peger Fees iagttagelse dog på, at kefalce-strukturens tredje analogi, Gud, spiller en rolle i den fortsatte argumentation.
} 
lægges eksklusivt om manden (Freedman \& Simon 1951, 61f). Grunden til, at manden ikke skal tilhylles, er altså, at han på en særlig måde - til forskel fra kvinden - er skabt i Guds billede. Den videre argumentation tilrettelægges imidlertid ud fra den anden ska-

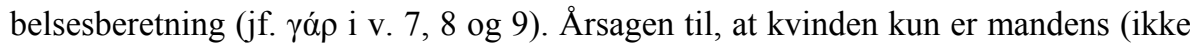
Guds) afglans, er, at hun er skabt af manden og for hans skyld (jf. 1 Mos 2, v. 18 og 2123). Ikke alene er en sådan udlægning af 1 Mos 1 gennem 1 Mos 2 problematisk, ${ }^{12}$ men logikken forbliver tilmed dunkel. For hvorfor skal manden ikke være tilhyllet, når han er Guds afglans, ligesom kvinden qua mandens afglans skal være det? ${ }^{13}$

Det er tilsyneladende slet ikke denne logik, der optager Paulus, når han argumenterer ud fra skabelsen. Frem for at rette fokus på menneskets skabelsesgivne særstatus fremhæver Paulus den skabelsesgivne kønsdifferentiering. Skabelsestanken skal således snarere understøtte det forudgående led i argumentationen, nemlig forestillingen om, at det er skamfuldt for mænd modsat kvinder at bede eller profetere tilhyllet (v. 4-6). Paulus lader således skammen og skabelsen tolke hinanden gensidigt, når han formaner imod, at mænd optræder og klæder sig som kvinder og vice versa.

Flere forhold bekræfter, at henvisningen til skabelsen skal underbygge og udlægge argumentet vedrørende skam: For det første skabelsesargumentets uafsluttede og inkonsistente karakter, som viser sig ved den manglende gennemførte logik i skabelsestanken i relation til tildækningen (jf. ovenfor). Endvidere består selve argumentationen i ( $\gamma \alpha \dot{\rho} \rho$, v. 7), at skammen udlægges ved hjælp af skabelsen: det skamfulde er at undsige sig skabelsen. Endelig bliver analogien mellem mændenes og kvindernes handlinger knyttet til det fælles kendetegn, at de er et angreb på det skabelsesgivne og det vil i denne sammenhæng sige kønsdifferentieringen. Det skamfulde ved, at mænd beder eller profeterer tilhyllede eller med langt hår, ${ }^{14}$ og kvinder utilhyllede, kortklippede eller ragede, består således ifølge Paulus i, at disse handlinger er en form for androgyni og transvestitisme, og som sådan indebærer de en protest imod og en negligering af det skabelsesgivne. ${ }^{15}$ Det vil jeg uddybe i det følgende.

\footnotetext{
${ }^{12}$ Det problematiske består især i, at gudbilledligheden i Paulus' udlægning eksklusivt gælder manden ( _ví $\rho, 1$ Kor 11,7), mens den i 1 Mos 1,27 udtrykkeligt tilregnes mennesket (__v $\theta \rho \omega \pi \circ$, LXX 1 Mos 1,27), både mand og kvinde.

${ }^{13}$ V. $7 \mathrm{~b}$ må være formuleret elliptisk, således at meningen bliver: "For en mand bør ikke tildække sit hoved, eftersom han er Guds billede og afglans. Men kvinden [bør tildække sit hoved, da hun] er mandens afglans" (jf. v. 4-6).

${ }^{14}$ V. 4 byder på et vanskeligt problem, idet forståelsen af $\kappa \alpha \tau \kappa \varepsilon \varphi \alpha \lambda \varsigma \quad \chi \omega v$ ikke er entydig ud fra sammenhængen. Spørgsmålet er, hvad manden har ned over hovedet? En beklædningsdel (slør) eller sit lange

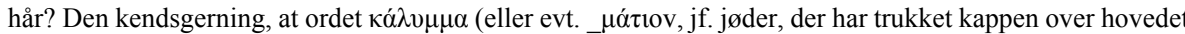
eller anvendt bedeslør under bøn i synagogen) ikke forekommer i teksten, samt at Paulus i v. 14 udtaler sig om samme fænomen ved hjælp af udtrykket $\kappa \mu_{-}$, taler for at læse $\kappa \alpha \tau+\kappa \varepsilon \varphi \alpha \lambda \_\varsigma \_\chi \omega \mathrm{v}$ som et idiomatisk

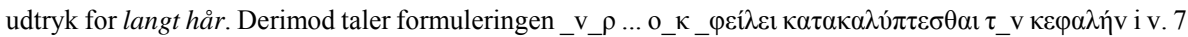
for at læse udtrykket $\kappa \alpha \tau \_\kappa \varepsilon \varphi \alpha \lambda \_\varsigma \_\chi \omega \mathrm{v}$ som gengivelse af noget ydre, hvormed man tildækker hovedet, dvs. et slør eller lign. Se uddybende Hurley 1972, 193-201.

${ }^{15}$ Det er grunden til, at Paulus gør spørgsmålet om tilhylning til et teologisk problem (Theissen 1983, 173f).
} 
Sammenhængen i argumentationen helt tilbage til v. 3 taler for, at henvisningen til englene i v. 10 skal læses som udtryk for, at de værner om skabelsen, Paulus netop har gjort rede for (Barrett 1992, 253f). Kvindernes tildækning som værn om det kønsspecifikke anskues her ikke som en underordning, men som en rettighed og et tegn på status,

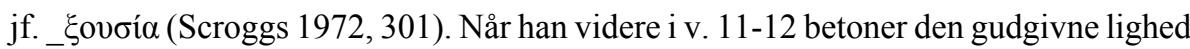
mellem kønnene, fastholder han samtidig kønsdifferentieringen (jf. forskellen mellem _ $\kappa$ og $\delta i \alpha ́$ ). Med denne ligheds- og gensidighedstanke har Paulus afværget en misforståelse af kefalce-strukturen som værende hierarkisk, ligesom han har værnet om en skabelsesgivet kønspolaritet og ydet modvægt mod et eventuelt ideal om kønsløshed (se afsnit V.1). Det skabelsesgivne hos Paulus i 11,2-16 er således ikke hierarkiet eller patriarkatet, men kønspolariteten og den dertil knyttede gensidige afhængighed. En negligering af kønspolariteten er et angreb på Guds suverænitet som skaber, jf. formuleringen $\tau_{-} \delta$ $\pi \alpha ́ v \tau \alpha \_\kappa \tau o_{-} \Theta \varepsilon o_{-}, \mathrm{v} .12$ (sammenlign kefalce-strukturens tredje analogi). ${ }^{16}$

Paulus' argumentation forud for og efter v. 13 taler imod at læse verset som udtryk for, at han så at sige opgiver resignerende eller i hvert fald afslutter diskussionen i appel til læsernes egen dømmekraft. Dermed ville han tage brodden ud af sin egen argumentation, hvilket næppe har været hensigten i en diskursiv tekst som denne. Snarere fremsætter han appellen i forventning om, at de selv vil være i stand til at indse rimeligheden i, at kvinder er tildækkede. Ligeså usandsynligt er det, at Paulus i v. 16 skulle afslutte sin udførlige argumentation med hellere at acceptere, at han ikke kan overbevise læserne, end at strides om emnet (Engberg-Pedersen 1991, 684-689).

Tilbage står spørgsmålet om, i hvilken forstand de skamfulde handlinger er en negligering af det skabelsesgivne. Kefalce-strukturens udformning har vist, at tekstens problemstilling vedrører mand-kvinde-forholdet i et religiøst perspektiv. Konteksten har indikeret, at dette perspektiv er afgudsdyrkelse. For nærmere at indkredse, hvilket religiøst forhold, der kan have foranlediget formaningen i 11,2-16, er det nødvendigt at afdække korinternes tidligere religionsudøvelse og det synkretistiske præg ved deres nuværende.

Korints menighed var meget sammensat, hvilket bl.a. fremgår af de tilbagevendende splittelser og stridigheder mellem forskellige grupperinger (fx 1,11-12; kapitel 8 og 10). Indkredsning af een bestemt religiøs baggrund er derfor næppe dækkende for samtlige fraktioner i menigheden. Ikke desto mindre tegnes der et billede af menigheden, som på afgørende måde bidrager til at give et indtryk af korinternes før-kristne religiøse observanser, til trods for, at Paulus i dele af brevet er stærkt polemisk (Barclay 1995, 247-67 vedr. rekonstruktionsforsøg på grundlag af polemiske tekster). Polemikken går bl.a. på, at Korintermenighedens medlemmer religiøst set regnes for tidligere afgudsdyrkere

\footnotetext{
${ }^{16}$ Henvisningerne i teksten til skabelsen taler for, at det først og fremmest er Gud som skaber, der trues i sin suverænitet (dvs. i sin status som det overordnede kefalæ) af korinternes adfærd. Modsat Hasler (1994, 19295), der udlægger kefale-strukturen i 1 Kor 11,2-16 som en frelsesordning, hvor mennesket skal underordne sig Kristus, der efter at have fuldendt sin frelsesfunktion skal underordne sig Gud, jf. det apokalyptiske sejrsudsagn i 15,28.
} 
$(12,2)$. Dertil kommer mere specifikt, at han bebrejder dem, at de lader eukaristien udvikle sig til drikkegilder $(11,21)$, og at deres brug af nådegaver under gudstjenesten antager ekstatiske former og minder om religiøst vanvid (14,23). Når man betragter disse oplysninger i lyset af det antikke middelhavssamfunds synkretistiske og polyteistiske miljø samt i lyset af, at menighedens medlemmer på dette tidlige stadium var konvertitter fra andre kulter, efterlader brevet det indtryk, at en række af menighedens medlemmer ikke konsekvent har opgivet deres tidligere religiøse adfærd, men tværtimod har søgt at forene den nye kristen-tro med tidligere religiøse anskuelser og praksis $(10,14$ 22) (Hasler 1994, 190f; udførligt uddybet af Chester 1999, der betoner forskelle mellem korinternes og Paulus' forståelse af kristentroens konsekvenser). Disse korinteres levemåde har givet anledning til stridigheder i menigheden, fx foranlediget af, at de er blevet budt på traktementer i afgudstempler og har deltaget i sammenkomster dér $(8,10)$. Dette er af andre i menigheden blevet opfattet som en form for synkretisme, der kan sidestilles med afgudsdyrkelse $(8,7.9-11 ; 10,28)$.

Efter således at have set nærmere på tekstens argumentationsrække, dens placering $\mathrm{i}$ brevet samt det portræt, der tegnes af Korintermenigheden i bred forstand, vil vi opsamle resultaterne i en foreløbig konklusion.

\section{Foreløbig konklusion}

Lad os først sammenholde resultaterne af de forskellige indre-tekstlige forhold, nemlig tekstens samlede argumentation, især ud fra skabelse og ære/skam, kefalce-strukturens udformning og kontekstens heuristiske funktion. Derved står vi tilbage med følgende: Paulus argumenterer imod en form for androgyni, hvor mænd og især kvinder har efterstræbt transvestitisme og kønsudligning ved at klæde og klippe sig svarende til det, som var sædvane for det modsatte køn. Denne skamfulde adfærd, som modvirker og undsiger det skabelsesgivne, har stået i forbindelse med afgudsdyrkelse. Der er således tale om en kønsligt motiveret synkretisme, som anfægter Guds suverænitet som skaber og især som det overordnede hoved. Ligesom 11,2-16 peger på, at kønslig forandring i form af androgyni har spillet en rolle i afgudsdyrkelsen (eller i hvert fald i dens synkretistiske konsekvenser), tyder den efterfølgende kontekst (11,17-21) på, at korinternes nadverfejringer har udviklet sig til drikkegilder for de velstilledes vedkommende. For så vidt denne efterfølgende kontekst bidrager til at identificere afgudsdyrkelsen i 11,2-16 yderligere, står vi over for en mulig rekonstruktion af tekstens anledning. ${ }^{17}$ Endelig understøtter kapitel 12 og 14 (sammen med 11,17-34) både tanken om, at anliggendet $i$ 11,2-16 vedrører menighedens rituelle fællesskab, og indikationen af, at det rituelle kunne antage ekstatiske former (14,2.9.16.23.27.29-30.33a).

\footnotetext{
${ }^{17}$ Muligvis skal også bemærkningen i 10,31 ses som en antydning af, at korinternes afgudsdyrkelse ikke eksklusivt er knyttet til spisning af kød, men også indeholder et drikkemoment.
} 
Selvom tekstens religiøse og sociale anledning for en umiddelbar betragtning forekommer dunkel, har ovenstående undersøgelse dog indkredset og identificeret problemstillingen betragteligt og vist, hvad vi kan slutte os til ud fra teksten selv og brevet som helhed. Med de resultater, som de indre-tekstuelle betragtninger har ført os frem til, har vi fået de grundlæggende kriterier, hvorudfra vi kan bedømme forskellige rekonstruktionshypoteser om, hvad vi derudover kan formode mere præcist har været tekstens anledning.

\section{Tekstens kønsligt motiverede synkretistiske anledning}

Overordnet set står vi over for følgende alternativer: Anledningen til synkretismen er noget indefrakommende, som fx en misforståelse af Paulus' forkyndelse af lighed mellem kønnene (Gal 3,28). Eller anledningen er noget udefrakommende fra fx forskellige kultsammenhænge, såsom kultisk prostitution (fx kultisk homofili) eller ophævelse af kønsdifferentieringen. I det sidste tilfælde kan korinterne have fulgt nogle forbilleder fra kultisk-rituelle sammenhænge fra deres fortidige religiøse praksis.

\section{V.1. En indre-kristen anledning}

Hvis synkretismen er foranlediget af noget indefrakommende, er der tale om, at den unge menighed i Korint har tolket den principielle ligestilling, som Paulus' forkyndelse i analogi med Gal 3,28 har indeholdt, på en måde, som har fremkaldt en irettesættelse fra Paulus' side. Som Theissen har gjort opmærksom på, taler såvel formuleringen i 12,13 som det i sammenhængen lidt overraskende udsagn i 11,11 for, at korinterne netop har kendt en tradition, der er analog med det egalitære budskab i Gal 3,28. Endvidere indledes afsnittet i 11,2 med en henvisning til, at korinterne holder fast ved et traditionsmateriale, som Paulus har viderebragt dem (Theissen 1983, 169-72). Hvis et sådant traditionsmateriale om lighed i Kristus mellem kønnene tilmed har været forbundet med en proklamation af dåben som iklædning af den nye, ikke-kønsspecifikke dragt, der hedder Kristus (jf. Gal 3,27), har det ifølge Theissen været nærliggende for korinterne at udlede, at kønsmæssige forskelle med hensyn til påklædning ikke har nogen berettiget plads i Kristus (Theissen 1983, 170; jf. D’Angelo 1995, 137). ${ }^{18}$

Det er min opfattelse, at Theissen underkender korinternes evne til at begribe det metaforiske i forkyndelsen (iklædningsmetaforen). Alligevel er det ikke vanskeligt at forestille sig, i betragtning af den emancipatoriske atmosfære, der har kendetegnet nogle af korinterne (fx 14,33b-36) (Lang 1994, 137f; Longenecker 1984, 79f), at Paulus'

\footnotetext{
${ }^{18}$ Den nye dåbsklædning, som de tidlige kristne blev iklædt umiddelbart efter selve dåbshandlingen, har muligvis ikke involveret slør for kvindernes vedkommende. Kvindernes utildækkede hoveder har således været et tegn på deres nye status, og de har med henvisning til denne dåbspraksis afvist at være tildækkede.
} 
egalitære budskab kan være blevet brugt som teologisk legitimation af, at kvinder ikke skal bære slør, fordi denne beklædningsdel ville markere en ulighed mellem kønnene. ${ }^{19}$

Når man tilmed betænker, at visse fraktioner af menigheden formodentlig har en præ-gnostisk baggrund (jf. bl.a. 1,5; 2,6-16; 6,12; 8,1-3), forekommer det plausibelt, at nogle af dens medlemmer kan have tilstræbt en udligning af kønspolariteten inden for menigheden. De kan således på grund af præ-gnostiske forestillinger meget vel have misforstået Paulus' budskab om lighed mellem kønnene og forbundet frelsen med forventningen om forløsning fra at være bundet til et bestemt køn. Idealet for den nye Kristus-identitet har i så fald været kønsløshed. ${ }^{20}$ Disse formodentlig præ-gnostisk influerede korintere har da fundet, at dette ideal anticipatorisk er kommet til udtryk ved, at både mænd og kvinder er døbte og deltager i de samme gudstjenester, både mænd og kvinder beder og profeterer, både mænd og kvinder deltager i menighedens måltidsfællesskaber osv. (jf. Wire 1990, 131 og 184-86 og Hurley 1972, 200f).

Den pneumatiske entusiasme, som har været fremherskende blandt disse kristne i deres påberåbelse af gnosis og åndsbesiddelse (jf. fx 14,23 og Paulus' relativering af tungetalens værdi i 14,1-25 såvel som hans advarsler imod uorden i forvaltningen af nådegaverne, 14,26-40), er gået hånd i hånd med en stærk optagethed af egne rettigheder, jf. dels de aforistiske formuleringer i 6,12 og 10,23, dels den mere udførlige redegørelse for fx problematikken vedrørende afgudsofferkød i 8,1-11,1. De har muligvis opfattet sig selv som transformerede til åndelige $(2,15)$, fuldkomne $(2,6)$ og vise $(3,18)$ og har således ment allerede at tilhøre den nye verden, jf. bl.a. Paulus' ironiske beskrivelse af deres selvtilfredshed og hans opgør med, hvad han opfatter som illusoriske forestillinger om at leve i fuldendelsen (fx 4,8, og 15,12-34 om fremtidigheden ved den kristne opstandelse).

På denne baggrund er det nærliggende at læse 1 Kor 11,2-16 som Paulus' irettesættelse af disse kristne, som har undsagt deres kønslige identitet (v. 4-6) og søgt at markere deres rettigheder til at handle på tværs og på trods af køn og dermed stadfæste idealet om kønsløs identitet. Mens korinterne har argumenteret ud fra nyskabelsen og dens antropologiske lighed, har Paulus argumenteret ud fra skabelsen og dens kønspolaritet. Hvor korinterne har repræsenteret en realiseret eskatologi, har Paulus fastholdt det nye livs fremtidighed. Hvor korinterne har set det som ærefuldt at være i Kristus, at have

\footnotetext{
19 BeDuhn $(1999,295-320)$ tolker udsagnet om englene i v. 10 som udtryk for, at korinterne har opfattet kristenlivet som en kønsløs engleeksistens, hvor skellene mellem kønnene er overskredet, mens Paulus derimod tager englene til indtægt for en kønsdifferentiering, idet de har virket med ved skabelsen og forårsaget, at mennesket eksisterer i to køn.

${ }^{20}$ Se uddybende hos MacDonald (1988, 282-92) der argumenterer for, at Paulus opponerer imod en kultisk transvestitisme, mere præcist en gnostisk androgyni. Ved at gå utildækket/utilsløret og eventuelt klæde sig som mænd har de korintiske kvinder bestræbt sig på at stige op i det ontologiske hierarki og blive som det kønsløse (eller rettere: kønsforenede, dvs. både mandlige og kvindelige) urmenneske som led i den kultiske tilbagevenden til det guddommelige. Variant af den præ-gnostiske hypotese hos Jervis (1993, 231-46), der mener, at korinterne har misforstået Paulus, fordi de har kendt til hellenistisk-jødisk midrash, hvor gudbilledligheden i 1 Mos 1,27 opfattes som udtryk for en oprindelig kønsløshed (fx hos Filon).
} 
ånden etc., har Paulus set det som skamfuldt at regne denne væren for hævet over den skabelsesgivne kønsdifferentiering.

\begin{tabular}{|c|c|}
\hline \multicolumn{1}{|c}{ Paulus } & Korintere \\
\hline Skabelse & Nyskabelse \\
\hline Kønspolaritet & Antropologisk lighed \\
\hline Futurisk eskatologi & Realiseret eskatologi \\
\hline $\begin{array}{c}\text { Skam: ophævelse af } \\
\text { kønsdifferentiering }\end{array}$ & $\begin{array}{c}\text { Ere: væren i Kristus, } \\
\text { indehavelse af ånden etc. }\end{array}$ \\
\hline
\end{tabular}

Skønt en sådan forståelse af baggrunden for 1 Kor 11,2-16 er mulig og kohærent i forhold til brevet som helhed, forbliver den dog en hypotese og udgør ikke som sådan et belæg for, at forklaringen skal søges i et indre-kristent sammenstød mellem divergerende opfattelser af kristen-tro (evt. dåb) og køn. Anledningen kan også være noget udefrakommende. I så fald kan samtidens opfattelser af seksualitet og ære/skam eventuelt kaste lys over, hvori det skamfulde og skabelsesstridige i v. 4-6 skulle have bestået.

\section{V.2. Et socio-biologisk rekonstruktionsforsøg ud fra samtidens forestilling om skam}

På grundlag af samtidige, hellenistisk jødiske kilder af Pseudo-Phokylides og Filon har Murphy-O'Connor peget på, at mænds lange hår ${ }^{21}$ har signaleret homoseksualitet, og at tilsvarende kvinders korte hår har signaleret lesbisk identitet og adfærd. Der er altså ikke blot tale om, at langt hår til mænd har været regnet for feminint, men at det mere specifikt har været et identitetstegn for homoseksuelle. Filon kan tilmed begrunde sin afstandtagen til homoseksualitet med argumenter, som er oplagte paralleller til 1 Kor

\footnotetext{
${ }^{21}$ Murphy-O'Connor tolker formuleringen $\kappa \alpha \tau_{-} \kappa \varepsilon \varphi \alpha \lambda \_\varsigma_{\_} \chi \omega \mathrm{v}$ som et idiomatisk udtryk for langt hår. Han finder det i øvrigt ikke sandsynligt, at Paulus ville have reageret så voldsomt som tilfældet er i 1 Kor 11,2-16, hvis der havde været tale om mænd, som bar et klæde på hovedet, eftersom Paulus fra sin jødiske opvækst har kendt præster, der bad med turban på hovedet. Det lange hår derimod kunne udløse den skarpe reaktion (1980, 483-85).
} 
11,2-16: Homoseksualitet (1) gør naturen til skamme (sml. 1 Kor 11,14), (2) gør manden selv til skamme (sml. 1 Kor 11,4.14) og (3) gør familien, landet og menneskeheden til skamme (sml. 1 Kor 11,16). Ikke kun Paulus' jødiske samtid har opfattet langt hår hos mænd som tegn på homoseksualitet, men også hos ikke-jødiske samtidige finder Murphy-O'Connor eksempler på, at mænds lange hår er blevet forbundet med homoseksualitet. Endvidere giver han eksempler på stoiske filosoffer, Musonius Rufus og Epiktet, der har opfattet mænds lange hår som et signal om kønslig flertydighed og en udviskning af kønsforskellen mellem mand og kvinde.

Kvinders korte hår har først og fremmest signaleret $\mathrm{u}-\mathrm{kvindelighed} \mathrm{i} \mathrm{mere} \mathrm{generel}$ forstand. Dog kunne kort hår også indikere lesbisk identitet ifølge Murphy-O'Connor. Primært var det lange hår dog en nødvendig forudsætning for, at kvinderne kunne lave de kunstfærdige opsætninger, som i samtiden blev anset for at være passende for kvinder. Langt hår kunne således gøre det ud for et slør, hvilket forklarer Paulus' udsagn i v. 15b (Murphy-O'Connor 1980, 488f). Hvis kvinder derimod ikke plejede håret på en passende måde, blev det regnet for skamfuldt, og de kunne i så fald lige så godt tage skridtet fuldt ud og fremtræde decideret mandlige, som Paulus sigter til i 1 Kor 11,6. Klippede kvinder sig korthårede, var det således indbegrebet af en bestræbelse på at skjule deres køn og i stedet fremtræde som mænd. De brugte således ikke håret til at fremhæve deres eget køn og dermed deres egen ære, men til at fremtræde ufeminint, hvilket ifølge Murphy-O'Connor generelt blev anset for skamfuldt. Hvad naturen lærer (v. 14), er således synonymt med, hvad der er socialt og biologisk konventionelt. Alt i alt peger Murphy-O'Connor på, at Paulus formaner generelt imod korinternes forsøg på at udviske kønsdifferentieringen ved at optræde som modsat køn. Desuden formaner han antydningsvis mere specifikt imod henholdsvis homoseksuel og lesbisk image (Murphy-O'Connor 1980, 483-91; uddybet i 1988, 267-69; endvidere Barrett 1992, 257 og Theissen 1983, 173-79).

Det fælles resultat af forsøget på henholdsvis en indre-kristen og en samtidig sociobiologisk rekonstruktion er, at Paulus' anliggende tolkes som et værn om kønsbevidstheden ud fra tanken om skabelse og ære/skam. Det troværdige ved disse tolkningsmuligheder er, at den androgyne adfærd er i overensstemmelse med, hvad brevet som helhed giver indtryk af med hensyn til i hvert fald dele af menigheden. Muligheden for, at der specifikt er tale om homofili, bekræftes imidlertid ikke af brevet, hvilket svækker denne tolkningsmulighed. ${ }^{22}$ Svagheden ved den indre-kristne rekonstruktion er desuden, at den ikke tager højde for placeringen af 11,2-16 efter behandlingen af afgudsdyrkelse $i$ kapitel 10 og afrundingen i 10,31-11,1 angående afgudsdyrkelsens ekklesiologiske og missionsteologiske implikationer.

Vanskelighederne ved en historisk rekonstruktion af, hvad der har influeret korintermenigheden, er mange. Herom vidner de meget forskelligartede resultater af forsøg på at afdække tekstens anledning. Tilsammen giver disse resultater mest af alt et kalej-

\footnotetext{
${ }^{22}$ Hvis homofili-hypotesen overhovedet kan regnes for plausibel, taler konteksten for, at det drejer sig om sakral homofili fx i forbindelse med kultisk prostitution.
} 
doskopisk billede af, hvori det skamfulde, som modsiger det skabelsesgivne, som Paulus sigter til i v. 4-6, består. Det må imidlertid være korinterbrevstekstens egne indikationer af, hvad problemstillingen vedrører, der skal afstikke kriterierne for, hvilke hypoteser der kan siges at være plausible. Flere af disse kriterier er ikke til stede i ovenstående hypoteser. I det følgende vil vi derfor koncentrere os om et rekonstruktionsforsøg, som drejer sig om en form for afgudsdyrkelse, der involverer et angreb på kønsbevidstheden, da det er, hvad de indre-tekstuelle indikationer har peget i retning af.

\section{V.3. Den dionysiske hypotese}

I sine undersøgelser af antikke græsk-romerske kulter med kvindelige deltagere peger Kroeger på sammenfald mellem især Dionysoskulten og nogle af korinternes religiøse særkender. Resultaterne af disse sammenligninger kan sammenfattes i tre fænomener, hvoraf det første ganske vist snarere er et bredt, folkereligiøst fænomen, end det er specifikt knyttet til Dionysoskulten. De tre fænomener er forbandelse, beruselse og promiskuitet.

I den antikke verdens græsk inspirerede folkereligiøsitet havde rituelle forbandelser vundet udbredelse. Det skete ofte i form af et menneskes påkaldelse af guder, fx Herkules eller Dionysos, med henblik på at bevæge guden til at forbande en person, som det pågældende menneske havde lagt for had. Guderne blev således taget i ed på hævn. Det kan være kristne udmøntninger af sådanne hedenske fortilfælde af rituelle forbandelser, Paulus advarer imod og erklærer uforenelig med den kristne åndsbesiddelse i 12,3.

I dyrkelsen af Dionysos som vingud er forskellige former for beruselse indgået (Keuls 1984, 287-89; Kraemer 1979, 55-80; Martin 1987, 94f). Korinternes nadverfejring røber en mulig indflydelse herfra. Nadverfejringen har nemlig udgjort et oplagt sidestykke til dionysiske festmåltider, når den har udviklet sig til et ædegilde med tilfælde af beruselse $(11,21$, jf. endvidere korinternes deltagelse i fester i afgudstempler, 8,10, og Paulus' advarsler mod afgudsdyrkelse i forbindelse med eukaristien, 10,14-21).

Den tredje antydning af, at nogle af korinternes religiøse fortid kan have bestået i tilknytning til Dionysoskulten, viser sig ved deres promiskuitet. Ifølge Paulus' bebrejdelser har korinterne været seksuelt frigjorte og følt stolthed og selvglæde over det $(5,2.6)$. Det indikerer ifølge Kroeger, at promiskuiteten har en kultisk begrundelse. I Korints synkretistiske miljø kan byens græske og romerske helligdomme, herunder den eventuelle sakrale prostitution i Afroditetemplet, meget vel have tilvejebragt den religiøse begrundelse og tradition for den promiskuitet, som også dele af den overvejende hedningekristne storbymenighed har praktiseret og søgt at forene med deres nyvundne kristne identitet. Paulus’ opgør med, at den ægteskabelige stand skulle have karakter af et teologisk prærogativ, og hans betoning af retten til cølibat (kapitel 7) kan meget vel have brod mod en sådan rituel promiskuitet, selvom den primcre teologiske begrundelse for hans ægteskabsmoral i kapitel 7 ligger i forventningen om snarlig parusi.

Mens der i kapitel 7 er tale om et implicit opgør med den generelle religiøse promiskuitet, peger Kroegers komparative studier på, at det implicitte opgør i 11,2-16 er rettet imod de kulter, hvor kønslig transformation har spillet en central rolle. Det har været et 
særkende for netop Dionysoskulten, at mænd har klædt sig kvindeligt og vice versa for at symbolisere et kønsligt skifte. Hengivenheden til Dionysos blev for mænds vedkommende udtrykt i slør og langt hår, mens kvinders blev udtrykt i, at de gik uden slør og lod håret klippe. ${ }^{23}$ Den mytiske begrundelse for dette symbolske kønsskifte er Dionysos' egen skæbne og androgyne karakter: Han blev opfostret som en pige og opfattet som både mandlig og kvindelig. Netop i den hellenistiske periode har fremstillingen af Dionysos udviklet sig fra en muskuløs atlet til en mere feminin og næsten androgyn figur (Bilde 1995, 97). I andre mere ekstreme kultsammenhænge som fx Kybelekulten findes eksempler på, at mænd kastrerede sig selv og bar kvindeklæder, kvindesmykker (øreringe m.m.) og slør (Kroeger 1987, 25-38; Kroeger \& Clark1978, 331-38; se dog Theissen 1983, 168, vedr. det omstridte ved netop Dionysoskulten med hensyn til slør og hårlængde).

Kraemers undersøgelser af Dionysos-kulten bekræfter ikke alene frugtbarhedsmagiens og frugtbarhedsriternes centrale rolle. Riterne indikerer tilmed, at forestillingen om at vende socio-biologiske roller på hovedet har været kendetegnende for netop Dionysoskulten, bl.a. i den hellenistiske periode. Når Dionysos er blevet hyldet som gud gennem rituelle danse, har danserne båret rituelle klæder, bl.a. har mænd iklædt sig kvindeklæder. Dette er sket i analogi med Dionysos’ egen legemliggørelse af begge køn. Dionysos selv repræsenterer således begge køns mulige kønsrolleændring. Androgynien udkrystalliserede sig også i, at kvindelige Dionysosdyrkere opgav deres traditionelle huslige pligter og børneopdragelse, $\mathrm{i}$ hvert fald midlertidig, til fordel for kultens jagt- og slagte-riter, hvor de kvindelige mænader efter sigende drog ud i skoven, fangede, sønderrev og fortærede kid. Dette indebar en opgivelse af den kvindelige identitet, herunder moderloyaliteten. Til gengæld dispenserede de ekstatiske riter for denne opgivelse af kønsrollen ved at lade kvinderne passe og amme de vilde dyrs nyfødte afkom (Kraemer 1979, 67f; endvidere Bilde 1994, 126f). ${ }^{24}$

\footnotetext{
${ }^{23}$ Ifølge Thompsons undersøgelser af græsk-romersk arkæologisk materiale (portrætter, statuetter og lign.) peger de konventionelle beskrivelser af Dionysosriterne på, at de kvindelige Dionysostilhængere ofte har haft løsthcengende hår. Andre portrætteringer tegner imidlertid billeder af kvinder med opsat hår (1988, 107-13). Gills undersøgelser peger på, at de kvindelige Dionysostilhængere i romersk influerede kredse (jf. Korint som romersk koloni) har været utildækkede og haft løsthængende hår, og at mænd med tildækket hoved har signaleret aktiv deltagelse i afgudsdyrkelse (1990,246-51 og 255). Gill mener imidlertid, at problemstillingen i 11,2-16 er socialt, ikke religiøst motiveret (s. 245-60): Mændenes klædedragt har ikke blot signaleret afgudsdyrkelse, men høj social status og været brugt til at skaffe sig anerkendelse i menigheden. Også Fiorenza $(1984,227 f)$ bekræfter, at de korintiske kvinders løsthængende, uopsatte hår skyldes indflydelse fra orgiastiske kultsammenhænge som $f x$ Dionysoskulten (bekræftes af arkæologiske fund fra Thessalonikiområdet $\mathrm{i}$ hellenistisk tid, jf. Bilde 1995, 97). Se endvidere Oster (1988, 488-97), der har dokumenteret, at det var romersk skik, at mænd var tildækkede ved bøn, offer m.m., og at Korint som koloni var under en sådan romersk indflydelse. En af de tekster, der bekræfter, at mænaderne havde løsthængende hår, er Euripides' Bakchantinderne. Witheringtons arbejder peger derimod på, at både jødiske, græske og romerske kvinder har haft tradition for at have tildækket hoved, også i rituelle sammenhænge (1988, 80-82, uddybet 1995, 233-35, hvad angår de romerske traditioner for tildækket hoved i religiøse sammenhænge).

${ }^{24}$ Uddybende om Dionysos' biseksualitet, hvor begge køn eksisterer side om side, men samtidig ophæver
} 
Sammenfattende peger Kroegers religionsfænomenologiske studier på tre sammenfald mellem korinterne og Dionysosdyrkerne, der taler for, at korinternes synkretisme har bestået $i$ en sammensmeltning af kristen-troen og tidligere religiøse erfaringer fra Dionysoskulten: (1) forbandelseshandlinger, (2) rituel beruselse og (3) religiøs promiskuitet. Kraemers undersøgelser bekræfter, at de to sidste fænomener er substantielle elementer i Dionysosdyrkelsen i hellenistisk tid. Endvidere betoner han, at ombytningen af socio-biologiske roller og værdier har haft en meget central plads i Dionysosriterne. Begge konkluderer desuden, at Dionysoskulten har haft et stærkt kvindeemancipatorisk præg (Kraemer 1979, 79f; Kroeger 1987, 28-30, 32-33), ${ }^{25}$ hvilket er påfaldende sammenligneligt med tendenser i Korintermenigheden generel $\mathrm{t}^{26}$ og med udformningen af formaningen i 1 Kor 11,2-16 specielt (adresseret til begge køn, men i særlig grad til kvinderne). Alt i alt forekommer hypotesen om en dionysisk baggrund for nogle af de hedningekristne i Korint samt antagelsen af en inkorporering af elementer fra denne kult i menighedslivet at udgøre et plausibelt forsøg på en rekonstruktion af foranledningen til 1 Kor 11,2-16.

\section{Konklusion}

Læsningen af 1 Kor 11,2-16 har vist tre ting. For det første, at Paulus ikke leverer en teologisk argumentation imod ligestilling mellem mænd og kvinder hverken $i$ almindelighed eller i en ekklesiologisk, gudstjenestelig sammenhæng. For det andet indikerer tekstens argumentation, herunder kefalce-strukturens udformning og argumenterne skabelse og ære/skam, perikopens placering mellem kapitel (8 og) 10-11,1 og 11,17-21 (videre 11,17-12,31 og kapitel 14) samt endelig brevet som helhed, at problemstillingen ikke er forholdet mellem kønnene som sådan, men dette forhold i en religiøs, rituel kontekst. Paulus gør op med en adfærd, hvis skamfuldhed består i, at den undsiger den skabelsesgivne kønspolaritet (og dermed begge køns integritet) og samtidig Guds suverænitet. Muligvis har korinterne i deres adfærd endvidere undergravet det ekklesiologiske og missionsteologiske hensyn, Paulus plæderer for, idet de har forårsaget splittelser og forarget nogle af brødrene, og dermed brudt med det etiske ideal om hensyntagen

hinanden: i Jameson (1993, 44-64). Også Henrichs (1982, 158f) beskriver den rituelle transvestitisme, som er indgået i Dionysoskulten, men mener ikke, der er belæg for at gøre dette til et udbredt fænomen i den hellenistisk-romerske periode.

${ }^{25}$ Kraemers undersøgelser afspejler dog samtidig, at kulten også har tiltrukket mænd (1979, bl.a. 57, 60, 69 og 71). Dette kan forklare Paulus' udsagn i v. 4. Endvidere har, ifølge Kroeger, særligt de græske kvinder i Dionysoskulten ved hjælp af ceremonielle råb udtrykt deres utilfredshed med samfundets mandsdominans. Kroeger ser dette som en mulig baggrund for Paulus' formaning i 1 Kor 14,34-35, ligesom hans formaninger til ro og orden under gudstjenesten frem for råb, tumult og ekstatiske aktiviteter underbygger antagelsen af en kultisk, fx dionysisk, baggrund, hvor man netop kendte til ekstase, ledsaget af larmende instrumenter (baggrunden for 1 Kor 13,1) (1978, 334f, og 1987, 29f).

26 Jf. den tidligere omtalte pneumatiske entusiasme, og jf. fx 14,33b-36. 
til de andre og værn om de svage i menigheden. Formodentlig har eksponenterne for denne synkretisme hentet inspiration fra præ-gnostiske forventninger om at blive forløst fra binding til et bestemt køn, ligesom de meget vel kan have hentet en teologisk legitimation i Paulus' egalitære budskab. Hvad Paulus har villet yde modvægt mod, er en synkretisme, hvis kendetegn er en emancipatorisk udligning af kønspolariteten og muligvis rituel beruselse, og hvis religiøse forudsætning er at finde i afgudsdyrkelse. Såvidt den indre-kristne rekonstruktion.

For det tredje er det muligt, at religionsfænomenologiske studier af Dionysoskulten i hellenistisk tid kan bidrage til at indkredse afgudsdyrkelsen. I hvert fald udgør Dionysos-hypotesen ${ }^{27}$ et seriøst indlæg i debatten om 1 Kor 11,2-16, eftersom den bekræftes af de kriterier, som teksten selv opstiller. De indre-tekstuelle kriterier peger endvidere på en præ-gnostisk kønsudligning. En mulig rekonstruktion kan i så fald bestå i en inspiration fra præ-gnosticisme i bred forstand, kombineret med en mere specifik påvirkning fra Dionysoskulten.

\section{Litteratur}

BARCLAY, JOHN M.G.

1995 "Mirror-Reading a Polemical Letter: Galatians as a Test Case", Stanley E. Porter \& Craig A. Evans, eds., The Pauline Writings, Sheffield, 247-267.

BARRETT, C.K.

1992 A Commentary on the First Epistle to the Corinthians, London.

BEDALE, STEPHEN

1954 "The Meaning of $\kappa \varepsilon \varphi \alpha \lambda \eta$ in the Pauline Epistles", The Journal of Theological Studies 5, 211-215.

BEDUHN, JASON DAVID

1999 “'Because of the Angels': Unveiling Paul's Anthropology in 1 Corinthians 11", Journal of Biblical Literature 118, 295-320.

BILDE, PER

1994 "Det religiøse liv i hellenistisk-romersk tid", Sigfred Pedersen, ed, Den nytestamentlige tids historie, Århus, 117-157.

BiLde, Pia Guldager

1995 "Dionysos i hellenistisk tid: fra fordybelse til forfladigelse?", Jan Zahle, Per Bilde, Troels Engberg-Pedersen \& Lise Hannestad, eds., Ideal og Virkelighed. Mennesket i kunsten fra Alexander den Store til dronning Kleopatra, Ishøj, 94-104.

BOUCHER, MADELEINE

1969 "Some Unexplored Parallels to 1 Cor 11,11-12 and Gal 3,28: The NT on the Role of Women", The Catholic Biblical Quarterly 31, 1969, 50-58.

BUSSMANN, C

\footnotetext{
${ }^{27}$ Når tolkningen forbliver en hypotese, skyldes det dels de manglende direkte referencer til Dionysoskulten i teksten selv, dels usikkerheden om Dionysoskultens rituelle praksis.
} 
1983 "Gibt es christologische Begründungen für eine Unterordnung der Frau im Neuen Testament?”, Gerhard Dautzenberg, Helmut Merklein \& Karlheinz Müller, eds., Die Frau im Urchristentum, Freiburg, 254-262.

CHESTER, STEPHEN J.

1999 Conversion at Corinth. An Exploration of the Understandings of Conversion Held by the Apostle Paul and the Corinthian Christians, unpublished PhD.-dissertation, Glasgow.

COPE, LAMAR

1978 “1 Cor 11:2-16: One Step Further”, Journal of Biblical Literature 97, 435-436.

D'Angelo, Mary Rose

1995 "Veils, Virgins, and the Tongues of Men and Angels. Women's Heads in Early Christianity", H. Eilberg-Schwartz \& W. Doniger, eds., Off with Her Head! The Denial of Women's Identity in Myth, Religion, and Culture, London, 131-164.

ENGBERG-PEDERSEN, Troels

1991 "1 Corinthians 11:16 and the Character of Pauline Exhortation", Journal of Biblical Literature 110, 679-689.

FEE, GORDON D.

1988 The First Epistle to the Corinthians, Michigan.

FIORENZA, ELISABETH SCHÜSSLER

1984 In Memory of Her. A Feminist Theological Reconstruction of Christian Origins, New York.

FITZMYER, JOSEPH A.

1993a "Another Look at КЕФА $\Lambda$ H in 1 Corinthians 11.3", New Testament Studies 35, 503-511.

1993b "Kephalé in 1 Corinthians 11:3", Interpretation 47, 52-59.

FREEDMAN, H.\& MAURICE SimON

1951 Midrash Rabbah, London.

GILL, DAVID W.J.

1990 "The Importance of Roman Portraiture for Head-Coverings in 1 Corinthians 11:2-16", Tyndale Bulletin 41, 245-260.

GUNDRY-VOLF, JUDITH M.

1997 "Gender and Creation in 1 Corinthians 11:2-16. A Study in Paul's Theological Method", J. Ådna, S.J. Hafemann \& O. Hofius, eds., Evangelium, Schriftauslegung, Kirche. Festschrift für Peter Stuhlmacher zum 65. Geburtstag, Göttingen, 151-171.

HASLER, VICTOR

1994 "Die Gleichstellung der Gattin. Situationskritische Reflexionen zu I Kor 11,2-16", Theologische Zeitschrift 50, 189-200.

HENRICHS, ALBERT

1982 "Changing Dionysiac Identities", B.F. Meyer \& E.P. Sanders, eds., Jewish and Christian Self-definition III, London, 137-160.

HuRLeY, JAMES B.

1972 "Did Paul Require Veils or the Silence of Women? A Consideration of 1 Cor. 11:2-16 and 1 Cor. 14: 33b-36", Westminster Theological Journal 35, 190-220.

ISAKSSON, ABEL

1965 Marriage and Ministry in the New Temple, A Study with Special Reference to Mt. 19.312 and 1. Cor. 11.3-16, Lund.

JAMESON, MiCHAEL 
1993 “The Asexuality of Dionysus", Thomas H. Carpenter \& Christopher A. Faraone, eds., Masks of Dionysus, Ithaca, 44-64.

JERVIS, L. ANN

1993 "But I Want You to Know...": Paul's Midrashic Intertextual Response to the Corinthian Worshipers (1 Cor 11:2-16), Journal of Biblical Literature 112, 231-246.

Keuls, Eva C.

1984 "Male-Female Interaction in Fifth-Century Dionysiac Ritual as Shown in Attic Vase Painting", Zeitschrift für Papyrologie und Epigraphik 55, 287-296.

KRAEMER, ROSS S.

1979 "Ecstasy and Possession: The Attraction of Women to the Cult of Dionysus", Harvard Theological Review 72, 55-80.

KROEGER, C.

1987 "The Apostle Paul and the Greco-Roman Cults of Women", Journal of the Evangelical Theological Society 30, 25-38.

Kroeger, Richard \& CATHERINE CLARK

1978 "An Inquiry into Evidence of Maenadism in the Corinthian Congregation", P.J. Achtemeier, ed., Society of Biblical Literature, Seminar Papers vol. II, Missoula, 331-338.

LANG, FRIEDRICH

1994 Die Briefe an die Korinther, Das Neue Testament Deutsch 7, Göttingen.

LONGENECKER, RICHARD N.

1984 New Testament Social Ethics for Today, Michigan.

MacDonald, Dennis Ronald

1988 "Corinthian Veils and Gnostic Androgynes", Karen L. King, ed., Images of the Feminine in Gnosticism, Philadelphia, 276-296.

MARTIN, LUTHER H.

1987 Hellenistic Religions. An Introduction, New York.

MuRPHY-O'CONNOR, JEROME

1976 “The Non-Pauline Character of 1 Corinthians 11:2-16?", Journal of Biblical Literature 95, 615-621.

1980 "Sex and Logic in 1 Corinthians 11:2-16", The Catholic Biblical Quarterly 42, 482-500.

1988 “1 Corinthians 11:2-16 Once Again”, The Catholic Biblical Quarterly 50, 265-274.

OSTER, RICHARD

1988 "When Men Wore Veils to Worship: The Historical Context of 1 Corinthians 11.4", New Testament Studies 34, 481-505.

Perriman, A.C.

1994 "The Head of a Woman: The Meaning of КЕФА $\Lambda$ in 1 Cor. 11:3", Journal of Theological Studies 45, 602-622.

SCHRAGE, WOLFGANG

1995 Der erste Brief an die Korinther, Evangelisch-Katholischer Kommentar zum Neuen Testament, Düsseldorf.

SCROGGS, ROBIN

1972 "Paul and the Eschatological Woman", Journal of the American Academy of Religion 40, 283-303.

THEISSEN, GERD

1983 Psychologische Aspekte paulinischer Theologie, Göttingen.

THOMPSON, CYNTHIA L. 


\section{Kønsligt hierarki eller religiøs androgyni}

1988 "Hairstyles, Head-coverings, and St. Paul. Portraits from Roman Corinth", Biblical Archaeologist, 99-115.

TROMPF, GARRY W.

1980 "On Attitudes Toward Women in Paul and Paulinist Literature: 1 Corinthians 11:3-16 and Its Context", Catholic Biblical Quarterly 42, 196-215.

WALKER, WILLIAM O.

1975 “1 Corinthians 11:2-16 and Paul's Views Regarding Women”, Journal of Biblical Literature 94, 94-110.

WALTKe, BRUCE K.

1978 “1 Corinthians 11:2-16: An Interpretation”, Bibliotheca Sacra 135, 46-57.

WiLSON, KENNETH T.

1991 “Should Women Wear Headcoverings?”, Bibliotheca Sacra 148, 442-462.

Wire, ANTOINETTE CLARK

1990 The Corinthian Women Prophets. A Reconstruction through Paul's Rhetoric, Minneapolis.

WITHERINGTON, BEN

1988 Women in the Earliest Churches, Cambridge.

1995 Conflict and Community in Corinth. A Socio-Rhetorical Commentary on 1 and 2 Corinthians, Michigan.

\section{Summary}

Only a few texts from the New Testament have been used and misused as have 1 Cor 11:2-16. A widespread misreading of the pericope consists in the interpretation that Paul there argued against equality between men and women generally or in the context of worship. The purpose of this article is twofold: To demonstrate why this reading is untenable and to argue for a more proper interpretation.

My reading is based on Paul's line of argument, including his remarkable formation of the kephale-structure and the position of the pericope between chapters (8 and) 10 and 11:17-21, respectively, as well as on the letter as a whole. All these things together indicate that the problem under discussion was not the relationship between the sexes as such, but this relationship seen in a religious, ritual context. Paul reproved a conduct whose shamefulness lay in its threat to both the gender polarity according to the creation and the sovereignty of God, a conduct which may also have caused divisions in the community. What Paul was arguing against, was a syncretism whose hallmark was an emancipatory equalization of gender polarity and, maybe, ritual intoxication and whose religious precedent was to be found in the worshipping of idols.

With this interpretation as the main criterion for testing different hypotheses put forward to explain the historical situation causing Paul to write the text, I have found that a possible reconstruction consists of an influence on the Corinthians from pre-gnostic thoughts in a broad sense, combined with a more specific influence from the cult of Dionysus.

Birgitte Graakjær Hjort

Adjunkt, ph.d.

Institut for Gammel og Ny Testamente

Aarhus Universitet 